International Journal of Instruction e-ISSN: 1308-1470 • www.e-iji.net

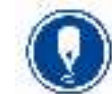

January $2021 \bullet$ Vol.14, No.1

p-ISSN: 1694-609X

pp. 395-410

Article submission code:

20190815125106
Received: $15 / 08 / 2019$

Revision: 27/06/2020
Accepted: 19/07/2020

OnlineFirst:24/10/2020

\title{
Strengthening Students' Self-efficacy and Motivation in Learning Mathematics through the Cooperative Learning Model
}

\author{
Akhsanul In'am \\ University of Muhammadiyah Malang Indonesia,ahsanul_in@yahoo.com \\ Eko Sabdo Sutrisno \\ University of Muhammadiyah Malang Indonesia, ekosabdoumm@gmail.com
}

Strengthening self-efficacy and motivation in learning mathematics gives impacts on the students' capability in the field of mathematics, and this may be conducted through a proper learning model, one of which is the cooperative learning model. The objective of this present research was to analyze students' self-efficacy reinforcement and their motivation in learning mathematics using the cooperative learning model with the Teams Games Tournament type. The subject was 28 male students in grade VIII of Junior High School Syaichona Cholil Samarinda in the 2017/2018 Academic Year. This research was conducted in the first semester using the algebraic system factorization. A Classroom action research model proposed by Kemmis and Mc Taggart was employed as the research guide. The data were collected through questionnaires to measure students' self-efficacy and motivation in learning mathematics, the teacher and students' activities forms to reveal their learning process, and interviews to complete the research results analyzed. The results showed that the cooperative learning model with the Teams Games Tournament type could improve students' ability in self-efficacy and motivation in learning mathematics as a whole. Based on these findings, the cooperative learning model with the Teams Games Tournament greatly facilitated the self-efficacy and learning motivation so that this model may be implemented for other materials in learning mathematics. TGT is able to stimulate better teaching and learning interaction, and this model is also able to improve learning quality, especially learning outcomes.

Keywords: reinforcement, self-efficacy, learning motivation, cooperative learning, teams' games tournament

\section{INTRODUCTION}

The problem of sincerity is under scrutiny in the field of education due to some frauds conducted by some students who were found to cheat in the examinations (Nurmayasarai \& Murusdi, 2015; Shara, 2016). Their reasons for doing the cheating were that the materials they learned were not tested in the examination, they did not study hard so that they did not know the answers, or they merely wanted to check their

Citation: In'am, A., \& Sutrisno, E. S. (2021). Strengthening Students' Self-efficacy and Motivation in Learning Mathematics through the Cooperative Learning Model. International Journal of Instruction, 14(1), 395-410. https://doi.org/10.29333/iji.2021.14123a 
answers since they were not sure of what they answered. The higher the students' selfefficacy, the higher their self-confidence in answering the problems in the examination will be (Hidayati, 2015; Nurmayasarai \& Murusdi, 2015; Pujiastuti, 2012, Shara, 2016). When their self-efficacy is higher, their desires to cheat are lower. On the contrary, if the level of their self-efficacy is low, they will not have high self-confidence in answering the problems in the examination.

Self-efficacy is one's confidence in his/her ability to do certain activities to reach specific goals (Bandura, 1994; Fitriana et al., 2015; Ormrod, 2009). Any individuals with high self-efficacy will always be convinced of what they do (Çiftçi \& Yildiz, 2019). When they fail in doing something, they will assume that the failure is caused by fewer efforts, low knowledge, and little skills. Individuals with a great performance like any challenges and tend to accept any intricate tasks because they think that the tasks are not challenges that should be avoided. Meanwhile, individuals with low self-efficacy will show doubtful attitudes and sheer away any jobs or tasks they think to be difficult because they assume that these jobs are threats. These individuals possess a low willingness to reach any predetermined goals. When they encounter difficult jobs, they will think of any weaknesses and obstacles they will face (Bandura, 1994; Friedman \& Schustack, 2008; Pajares, 1996).

A Cooperative Learning Model with Teams Games Tournaments (TGT) type is employed to reinforce students' self-efficacy and result in some differences in learning results compared with the students taught using the direct learning model. Annurwanda (2017) stated that this model has positive effects on students' self-efficacy in learning mathematics and their learning motivation. Nurmahmidah (2017) showed that students' learning achievements and motivation go up after a Cooperative Learning Model with TGT type is applied. Learning motivation is anything existing in individuals that enliven, direct, and maintain certain behaviors that keep the students to continuously move to reach their desired goals (Major et al., 2006; Ormrod, 2009). The application of the Cooperative Learning Model with TGT type may augment the learning results among the students in grade XI in State Vocational High School Semester I. It is also the case in the results revealed by some researchers (Asih, 2017; Nurmahmidah, 2017; Son \& Tanines, 2016) in which this model may also improve the students' motivation in learning mathematics in each learning cycle.

Cooperative learning is a learning model teacher employ in teaching with the goal to help improve students' learning results and their social skills, and also upgrade their learning responses and activities (Ismail et al., 2019). Before utilizing the cooperative learning model, teachers arrange students into some small groups to solve provided problems together (Herreid, 1998; Khan \& Inamullah, 2011; Salam, Hossain, \& Rahman, 2015; Slavin, 1980; Van Wyk, 2011). This learning model is selected since it may offer better learning results compared with those offered by the conventional learning model (DeVries, 1976; Salam et al., 2015; Sharan, 1980; Slavin, 1980; Van Wyk, 2011; Veloo \& Chairhany, 2013; Tarim, \& Akdeniz, 2008). Students' Selfefficacy and motivation in learning mathematics are greatly needed to reduce students' desire to cheat (Shara, 2016). Therefore, one of the efforts to boost their self-efficacy 
and motivation is by adopting the Cooperative Learning Model with TGT type. In this present research, the problem to examine is expressed in the following questions: How is the cooperative learning model with the team game tournament type implemented? Furthermore, how is the result of learning mathematics using cooperative learning with the team game tournament type?

\section{Literature Review}

Self-efficacy is any ability to solve what is intended or to reach a certain goal (Bandura, 1994; Friedman \& Schustack, 2008). It is divided into three dimensions: level, strength and generality (Bandura, 2006; Pajares, 1996). The level dimension deals with the intensity of difficulty of a task one believes to be able to resolve. The strength dimension is an individual's belief in being able to solve a problem, and the generality dimension is a different situation where an individual feels sure to his/her ability (Maysaroh, 2012; Ramlan, 2013; Shara, 2016; Soekanto, 2000). It is the three dimensions that may be used as the basis in making questionnaires on self-efficacy (Anandari, 2013; Pratiwi, et. al., 2015).

One's Self-efficacy comes from four sources: 1) enactive mastery experience, an individual's experience of success greatly affects self-efficacy because it is from real experience; 2) vicarious experience, self-efficacy is influenced by other individual experiences. An individual's observation of success in solving a certain problem will improve the individual's self-efficacy; 3) verbal persuasion, one who believes in his ability to master a task given will probably exert greater efforts than the one is full of doubt and the one who thinks of his/her weaknesses when trouble emerges, and 4) physiological and affective states, in evaluating his/her ability, an individual may depend on the physiological and emotional states he/she experiences. Besides the physiological state, the mood may also influence one's self-efficacy.

There are four factors influencing the development of self-efficacy: 1) self-control orientation, self-efficacy is intended to the feeling of confidence in someone concerning his/her ability to solve a problem. This is required to developed positive self-efficacy; 2) situational factor, some situations call for higher abilities or skills than others; as a result, self-efficacy may be more varied; 3) an individual's status or roles in his/her environment, an individual with higher status compared with that in an environment possesses a higher level of self-efficacy than those with lower status, and 4) external incentive or reward an individual receives. The greater the reward an individual gets when completing a task, the higher the self-efficacy one receives (Anandari, 2013; Pudjiastuti, 2012; Ramlan, 2013). Self-efficacy has negative and significant effects on students' cheating behaviors. The higher the self-efficacy one possesses, the lower the student's desire to cheat will be. On the contrary, the lower the self-efficacy a student has, the higher the student intends to cheat (Hidayati, 2015; Nurmayasari \& Murusdi, 2015; Pudjiastuti, 2012; Shara, 2016). The correlation among motivation, self-efficacy and learning outcomes is described as shown in Figure 1. 


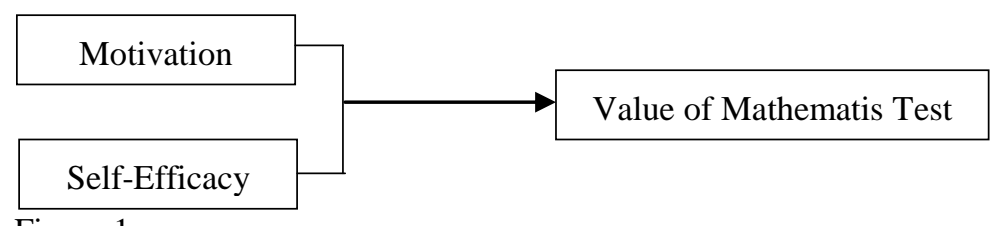

Figure 1

Correlation among motivation, elf-efficacy and value of mathematics test

Learning motivation is something existing in an individual that livens up, leads, and sustains a student's certain behavior so that he or she will continuously move (Major et al., 2006; Ormrod, 2009). Motivation is one of the crucial factors in the learning process to reach an intended achievement. Learning motivation influences learning results in mathematics (Fitriati, 2017; Syamarro, et.al., 2015; Tossavainen \& Faarinen, 2019). When one possesses a low motivation in learning mathematics, his/her achievement in mathematics will also below. This motivation will promote someone to study forever. Students' learning motivation is affected by two factors: internal and external. The Internal factor is the one from the student him/herself, for example, his/her desire and intention to succeed, or expectations to reach, meanwhile, the external factor is the factor coming from out of the student him/herself, such as rewards, conducive learning environment or interesting learning activities (Major et al., 2006; Ormrod, 2009; Sardiman, 2009). Learning motivation has some functions. First, it may be used as the activator to learn. When one has the motivation to learn, she/he certainly will always show a strong desire to learn. A student with high motivation will continuously develop better activities, creativity, and initiatives. Second, it determines the direction of action towards a goal. When a student expects to have good grades, his/her learning motivation will lead him/herself not to conduct any actions that may hinder him/her from reaching the planned goal. The last, it promotes any efforts to attain high achievement. Motivation deals with achievements and learning results. Good learning motivation will give good results. Assiduous efforts complemented with high motivation will show great achievement. A student's intensity motivation will exceedingly affect the level of his/her learning accomplishment. (Fitriati, 2017; Sunarsih, 2009).

Learning motivation may be grown or developed through various ways, some of which are by giving rewards to students who are able to reach the target the teacher intends, providing students with competitors in attaining the target, or giving punishment. Punishment may be applied if students show very low motivation. This low motivation may be seen from the students' performance in doing their home works, for example, or in their indifference in the classroom, especially when the teachers explain subjects (Sunarsih, 2009). Learning motivation is negatively and significantly related to students' desires to cheat (Eshet et al., 2012; Olanrewaju, 2010). The relation is that the higher motivation students show, the lower the students' intentions to cheat will be. 


\section{METHOD}

\section{Research Approach and Type}

A quantitative and qualitative approach was adopted in this present research, while the research type was a classroom action research intended to strengthen students' selfefficacy and motivation in learning mathematics using a Cooperative Learning Model with TGT type. The quantitative approach is adopted to analyze the effects of selfefficacy and motivation on the learning achievement, while the qualitative approach is adopted to describe the learning implementation through the classroom action research.

\section{Research Subject}

The research subject was the male 28 students in Grade VIII in Junior High School Syaichona Samarinda in the 2017/2018 Academic Year. This research was carried out in Semester II with the material of Algebraic factorization. The subjects were neither grade VII nor grade IX because grade VII students were still adjusting the new learning environment from elementary school to secondary school, and grade IX students were preparing for the national exam. Besides, the learning material used as research was in junior high schools.

\section{Research Design}

The action research model adopted was the one proposed by (Kemmis et al., 2014) as the guide to conducting the research, consisting of four stages, planning, implementation, observation, and reflection. The plan of this classroom action research model consisted of two cycles where each cycle was performed in line with what change to gain. Based on the research result, it indicates that this research can be completely finished within two cycles. When in this classroom action research, some weaknesses are identified, and the predetermined target is not achieved, some improvements are made in the planning and implementation of the next cycle. The step taken in this model started from planning, implementation of the action, observations, and reflections, see figure 2.

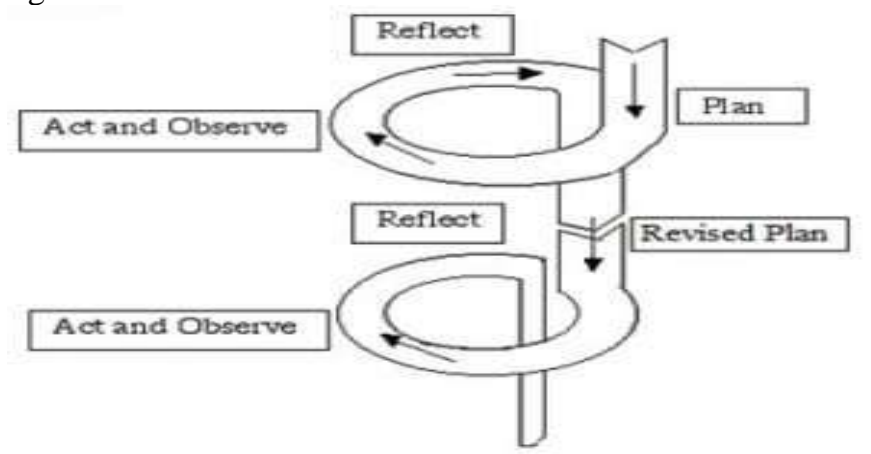

Figure 2

Cycle of action research 


\section{The Technique of Data Collection}

These data were collected through questionnaires. Questionnaires on students' selfefficacy and motivation in learning mathematics were administrated before and after the learning processes. The statements in the questionnaires on self-efficacy were made on the basis of Bandura's three dimensions, namely level, strength, and generality, where the number of the statements in the questionnaires on self-efficacy was 31 (Anandari, 2013). The results of the try-out of the self-efficacy questionnaires, conducted in the same school but in different classes, and the results showed the highest significance of 0.02 and the lowest one at 0.00 . Therefore, as a whole, the whole instrument is valid (Effendi \& Tukiran, 2012)

The questionnaires on the students' motivation in learning mathematics are based on Herzberg's two-factor model theory. The indicators for the intrinsic motivation are achievement, responsibility, and recognition, while the extrinsic ones are the condition of the learning environment, the relationship with peers, the relationship with the teachers and rewards in learning (Wardhani et al., 2015; Wizaksana, 2012). Like in the questionnaires on the self-efficacy, in the questionnaires on motivation, a validity test was also made, the result of the try-out of the questionnaires on the motivation in learning mathematics showed the highest significance level for each item of 0.02 , so as a whole the instrument is valid. The reliability of the try-out of questionnaires on students' self-efficacy and motivation in learning mathematics was 0.935 and 0.940 , respectively. This may be categorized into high since it approaches 1 (Effendi \& Tukiran, 2012).

\section{Teacher's and Students' Activity}

The teacher's and students' activity forms in this present research were intended to catch sight of the learning process that happened in the classroom. The goal of these activities served as the evaluation of the implementation of the learning process, whether it would be in line with the learning implementation plan, see table 1 .

Table 1

Activity of teacher and students

\begin{tabular}{ll}
\hline \multicolumn{1}{c}{ Activities of Teacher } & \multicolumn{1}{c}{ Activities of Students } \\
\hline The teacher explains the subject & Students pay attention to the teacher's explanation \\
\hline $\begin{array}{l}\text { The teacher asks students to read the books to } \\
\text { identify things they want to know }\end{array}$ & $\begin{array}{l}\text { Each member of groups reads the material to } \\
\text { identify things they want to know }\end{array}$ \\
\hline $\begin{array}{l}\text { The teacher asks students to pose a question if } \\
\text { there is unclear things }\end{array}$ & $\begin{array}{l}\text { Students pose questions about materials they do } \\
\text { not understand }\end{array}$ \\
\hline $\begin{array}{l}\text { The teacher has students answer the questions } \\
\text { available in the book }\end{array}$ & $\begin{array}{l}\text { Students discuss with each member of the group to } \\
\text { answer questions }\end{array}$ \\
$\begin{array}{l}\text { The teacher guides students to process the obtained } \\
\text { information in order to find the patterns of } \\
\text { problem-solving }\end{array}$ & $\begin{array}{l}\text { Students process the obtained information to find } \\
\text { patterns and make inferences }\end{array}$ \\
\hline $\begin{array}{l}\text { The teacher has students submit the result of } \\
\text { observation and conclusion which are made based } \\
\text { on the results of the analysis in written or spoken } \\
\text { form }\end{array}$ & $\begin{array}{l}\text { Students submit the result of observation and } \\
\text { conclusion based on the results of the analysis in } \\
\text { written and spoken form }\end{array}$ \\
$\begin{array}{l}\text { The teacher holds a tournament at the end of } \\
\text { learning and gives awards }\end{array}$ & $\begin{array}{l}\text { Students join the tournament held by the teacher } \\
\end{array}$
\end{tabular}




\section{The Technique of Data Analysis}

The results of the administration of the questionnaires were analyzed by giving scores for each statement in the questionnaires. Each statement was scored on the basis of the answers the students chose.

\section{RESULTS}

On the basis of the observations which were strengthened through the results of the interviews with some teachers of subject matters, a problem was identified that teachers were still difficult in solving students' cheating action when either they did tests or home works. This is proved by the wrong answers in the same item numbers. When some clarifications were made to some students, they admitted that the results of tasks and tests they had been from their cheating actions. Students felt that they were not sure about the answers or their own abilities. They thought that the answers made by their classmates must be correct, although, in fact, their answers are not always right.

After making dialogues with the teachers of mathematics in the school, it was found that the material taught was the arithmetic operation in the algebraic form. The success in each cycle was measured with the average score of the students' self-efficacy and motivation in learning which is higher from or the same with $61 \%$ and the addition of the percentage of the average score on students' self-efficacy and motivation in learning mathematics than before.

Moreover, it is also necessary to pay attention to the percentage of the development of some students' self-efficacy and motivation in learning mathematics. When in the learning process, some deficiencies were identified, and the predetermined target was not reached, some reflections and improvement in the planning and implementation in the next cycle were made.

As stated above, it is shown that each cycle consisted of four aspects studied: planning, implementation, observation, and reflection. The four aspects will be described as follows.

\section{Planning}

After it was determined that the cooperative learning model with the Teams Games Tournament type in the material of the algebraic factorization would be used, the researchers prepared various instruments with the help from the teacher such as making the learning implementation plan, the worksheets that would be distributed to the students for each meeting, the problems for the tournaments at the end of each learning activity and also the questionnaires on students' self-efficacy and motivation in learning mathematics. The questionnaires were adapted from the previously validated questionnaires.

\section{Implementation}

The activities in the first cycle comprised of five sessions. The first session discussed the nature of term, variable, coefficient, constant, like the term, unlike term with one's own sentence, coefficient of a variable in an algebraic form, and like or unlike algebraic 
form. One's own sentence means writing based on their own understanding of the nature of the term, variable, coefficient, constant, line, and unlike terms. The result was that some groups still wrote the nature of the problems, as stated in the book.

The second and the third session reviewed the results of addition and reduction operations in the algebraic form for some terms. This review took two sessions based on the advice from the school teachers. On the basis of the observations and interviews with some teachers, the students in the school still had some weaknesses in solving problems dealing with addition and reduction operations. Sometimes, some students had still not understood the intention of the problems related to the positive or negative numbers operated with addition or reduction. It is expected that after two sessions, students would have a better understanding of the problems.

The fourth session discussed the multiplication of a constant and a single algebraic term, the multiplication of a constant and a single algebraic term, the multiplication of a double-algebraic term, and the division of a single-algebraic term to a single term in an algebraic form. The results from the students' worksheet showed that there was merely one group that had not got maximal scores in this meeting. The fifth meeting talked about the results of exponents in the algebraic form.

The second cycle consisted of five sessions. In the first session, the researchers presented the materials of LCM and GCF in the single-term in an algebraic form. In this session, the students did not have a lot of difficulties since the principle in doing the problems are the same as solving the LCM and GCF from some numbers they had learned in their elementary school. The second session examined an algebraic factorization using GCF, the factorization of the difference of the two quadratic forms, the factorization of $x^{2}+2 x y+y^{2}$ and $x^{2}-2 x y+y^{2}$ forms. In the third session, the algebraic factorization of the $a x^{2}+b x+c$ form where $a=1$ and the algebraic factorization of the $a x^{2}+b x+c$ form where $a \neq 1$. The fourth meeting deepened about the multiplication of a constant and a single algebraic term, the multiplication of a constant and a single algebraic term, the multiplication of a double-algebraic term, and the division of a single-algebraic term to a single term in an algebraic form, The fifth meeting discussed more about the results of the exponents in algebraic form.

Motivating the students in the second session was more highly given because the problems they would encounter were not as easy as those in the first cycle, and the efforts made to improve the students' motivation and self-efficacy after the second cycle was expected to be able to attain the minimum criteria of success. The results of the group score in the first session in this cycle were not as good as those in the previous cycle. Therefore, the teachers were required to guide and also motivate their students.

\section{Observations}

The observation of the learning process was not merely focused on the teachers but also the students during the implementation of the learning activities (see table 1). Learning in each cycle started from praying to the presentation of the learning objectives and giving apperception before coming into the main material. Before presenting the material, the teachers tried to develop the materials in the classroom. When the students 
should work in groups, the teacher asked them to assemble in the groups that had been arranged before, and each group consisted of four students. The teacher always motivated the students to do their best to finish the given problems. Before the learning process ended, a tournament was held. The rules of the tournament were designed as an inter-student competition where students from one group competed with those from other groups. Before the competition started, the heads of groups wrote the order of students in the group who should answer the problems. This order is intended to make the teacher understand the ability of each student and train the students to be responsible for understanding the material. The materials in the tournament problems were made on the basis of the materials discussed in the same day. Rewards were given to the group with the highest score in each session. The group with the highest score received rewards in the form of a snack. Other groups that had not won the competition were still given rewards in the form of applause and compliment and motivation to win the game in the next session. At the end of the class, the teacher concluded the materials and gave a chance to the students to ask questions and also make evaluations through a questionand-answer session.

In the first and second sessions, the teacher had some difficulty in making the students active in the classroom. The students noticed the teacher's explanation of the material, but the feedback from the students was low as shown by the students' answers when the teacher asked questions about the material and also fewer spirits exhibited by the members of the groups in the workgroup sessions. In the tournaments in the first and second sessions, the condition of the class was always noisy; even the students who were not active in the workgroups tried to answer the problems, although the answers were not systematic.

Before starting the third session, the teacher told additional rules to the students. If there was a student who was not active in the discussion group, this would influence the end grade of the group. In the implementation, some students in a group were found not to be active, but other students from other groups did not let the inactive students but helped them do the problems. In the second cycle, the implementation in each session was not different from that in the first cycle. As usual, the teacher opened the lesson by praying fist, conveyed the learning objectives, gave apperception, and then came to the material. In the part of group work, the teacher requested the students to assemble in their own groups. The teacher still tried to motivate the students to try to do their best to answer the problems.

Before the learning activities ended, a tournament was held. The implementation of the tournament was the same as that in the first cycle. Av Reward was granted to the group with the highest score in each session. The group was given a reward in the form of a snack. Other groups that had not won the tournament were also praised with applause and praise and also motivation that in the next session, they would become the champion. At the end of the session, the teacher concluded the material and gave a chance to the students to ask questions and to make evaluation through a questionanswer session. 
In the third session, some students complained that the problems were difficult whereas they just read the problems and had not tried to do the problems. To motivate them, the teacher stated that no problem is difficult as long as students are willing to learn. The students should not have thought that problems are difficult; they assumed that all problems are easy. It is the students' way of thinking that should be changed. When one hates something, one will not understand it. It is also the case in mathematics. When one abhors it, one will not understand how to appreciate it, and this makes one avoid learning mathematics. In this session, the teacher was busy answering questions from some students who had not understood the material. In the third session in cycle 2, students showed great spirits again. Some of them still thought that if the problems were difficult, other classmates reminded them and asked them to try to find the answers to the problems instead of complaining.

\section{Reflection}

Some difficulties in making the students active to give their responses to work in groups and to reduce some noisiness during the tournament in the classroom in the first and second sessions, the teacher found solutions to the problems at the end of the session. The additional rules conveyed in the third session would not directly change the situation. Some students were still not active, other members of the groups asking the inactive students to help them do the problems step by step ameliorated the situation. The additional rules in the tournament created the situation in the classroom to be still noise but ordered. No student answered the problems arbitrarily. In the fourth and sixth sessions, students dynamically contributed to their own groups, and the activities in the tournament run smoothly and orderly. Then dealing with the results of the questionnaires provided and the activities in doing the exercises, the following would be presented.

The results of the questionnaires on students' self-efficacy and motivation in learning mathematics, students showed a relatively high improvement. It was shown in the precycle, cycle I, and cycle II that the learning process could develop students' selfefficacy and motivation in learning mathematics. The summary of the results of the questionnaires is presented in Table 2 .

Table 2

Results of questionnaires on students' self-efficacy and motivation in learning mathematics

\begin{tabular}{llll}
\hline \multicolumn{1}{c}{ Aspect } & Pre-cycle & Cycle I & Cycle II \\
\hline Self-efficacy & $56,39 \%$ & $59,62 \%$ & $64,89 \%$ \\
\hline Motivation in Learning Mathematics & $56,68 \%$ & $59,95 \%$ & $66,96 \%$ \\
\hline
\end{tabular}

The scores in mathematical tests were used to see the correlation between the motivation in learning and the test scores and students' self-efficacy and their test scores. Before making the correlation test, tests of normality and linearity were made. To do the normality test of each variable, the authors adopted the Kolmogorov Smirnov Test with the SPSS application.

The correlation between self-efficacy and the learning results in mathematics was 0.862 . This result showed that self-efficacy was positively correlated with the learning results 
in mathematics. The correlation of the motivation in learning mathematics and the learning results in mathematics was 0.819 , meaning that the students' motivation in learning mathematics was positively correlated with the learning results in mathematics, as shown in Table 4.

Table 3

Correlation between self-efficacy and the learning results in mathematics (LRM)

\begin{tabular}{llll}
\hline & & SE & LRM \\
SE & Pearson Correlation & 1 & $0.862^{* *}$ \\
\cline { 2 - 4 } & Sig. (2-tailed) & & 0.000 \\
\cline { 2 - 4 } & $\mathrm{N}$ & 28 & 28 \\
\hline \multirow{2}{*}{ LRM } & Pearson Correlation & $0.862^{\text {** }}$ & 1 \\
\cline { 2 - 4 } & Sig. (2-tailed) & 0.000 & \\
\cline { 2 - 3 } & $\mathrm{N}$ & 28 & 28 \\
\hline
\end{tabular}

**. Correlation is significant at the 0.01 level (2-tailed).

To recognize the effects of self-efficacy and motivation in learning mathematics and the learning results in mathematics, a linear regression test was carried out, as presented in Table 5. Since the level of significance is $0,000<0,005$, self-efficacy and motivation in learning mathematics simultaneously affects the learning results in mathematics.

Table 4

Correlation between the motivation in learning mathematics and the learning results in mathematics

\begin{tabular}{llll}
\hline & & LRM & Motivation \\
\hline \multirow{2}{*}{ LRM } & Pearson Correlation & 1 & $0.819^{* * *}$ \\
\cline { 2 - 4 } & Sig. (2-tailed) & & 0.000 \\
\cline { 2 - 4 } Motivation & $\mathrm{N}$ & 28 & 28 \\
\cline { 2 - 4 } & Pearson Correlation & $0.819^{* *}$ & 1 \\
\cline { 2 - 4 } & Sig. (2-tailed) & 0.000 & \\
\cline { 2 - 4 } & $\mathrm{N}$ & 28 & 28 \\
\hline
\end{tabular}

**. Correlation is significant at the 0.01 level (2-tailed).

To understand the extent to which the independent variable contributes to the dependent variable, the value of $\mathrm{R}^{2}$ may be considered. The value of $\mathrm{R}^{2}$ was 0,746 , or $74.6 \%$ as presented in Table 8. It means that self-efficacy and motivation in learning mathematics influenced around $74.5 \%$ to the learning results in mathematics, while the rest $25.4 \%$ was affected by other variables out of the research

Table 5

Linear regression test

\begin{tabular}{lllllll}
\hline \multicolumn{2}{l}{ ANOVA $^{\text {a }}$} & & & & \\
Model & Sum of Squares & df & Mean Square & F & Sig. \\
\hline 1 & Regression & 2146,912 & 2 & 1073.456 & 36.715 & $0.000^{\mathrm{b}}$ \\
\cline { 2 - 7 } & Residual & 730,945 & 25 & 29.238 & & \\
\cline { 2 - 6 } & Total & 2877,857 & 27 & & & \\
\hline
\end{tabular}

a. Dependent Variable: HBM

b. Predictors: (Constant), Motivation, SE 


\section{DISCUSSION}

The research results on self-efficacy showed that there is some increase in each cycle and proved that the use of the Teams Games Tournament model gave positive effects on the students' self-efficacy (Annurwanda, 2017). The increase in self-efficacy in the second cycle is greater than that in the first cycle. This showed that students' selfefficacy and motivation in learning mathematics improved, and their cheating habits would be reduced or even omitted at all. This may decrease the students' habits in doing their tasks as Nurmayasari \& Murusdi (2015) stated that cheated when they did their tasks.

The research results also suggested that learning experiences through problems may help them solve mathematical problems well either individually or collectively, and this may be used as their capital to solve any problem-solving skills in their learning activities. It is in line with the expert's opinion that such problem-solving skills may become the students' provisions in joining into any tournament activities (Armita \& Marsigit, 2016). According to some studies, the students' mastery of the learning materials may also improve their self-efficacy in answering questions in the tournaments without asking the answer from other members of their own groups (Armita \& Marsigit, 2016; Zuya et al., 2016).

The use of the cooperative learning model with the TGT type also solved the students' low motivation in learning mathematics and their low self-motivation and the use was also a proper decision since it may work out the two problems, and students may learn mathematics in a more relaxed fashion (Asih, 2017). Related to motivation, the results of this study are different from the research of Huang et al., (2017), which shows that the experiments conducted between the two groups, namely the experimental class and the control class, indicated no significant differences regarding with the learning motivation. Game in the form of a tournament implemented at the end of a learning session requires students to be responsible for themselves or their groups so that they may be able to compete with other groups. This causes students to be always to keep their own spirits so that they will not lose any games from their other classmates (Asih, 2017). On the basis of this research results, it can be stated that the cooperative learning model with the TGT type may improve the percentage of the students' motivation in learning mathematics and their self-efficacy. This indicates that interactions that occur during learning activities can increase motivation in learning mathematics, as the findings of research that have been done (Kiemer et al., 2015). In addition, games that provide interaction in learning can also increase learning motivation (Durksen et al., 2017).

The correlation between self-efficacy and the grades of the students' tests was 0,862 , and the coefficient correlation of the students' motivation in learning mathematics and their test results were 0.819 . This reveals that students' motivation in learning mathematics and their self-efficacy is positively correlated with their test results (Skaalvik \& Skaalvik, 2009). The results of this present research do not only answer the problem of how to reduce or even omit the students' cheating habits but are also beneficial as inputs to improve their test results. A positive correlation between their 
self-efficacy and their motivation in learning mathematics and their test results make the teachers think about their learning process to improve the two aspects. The use of the cooperative learning model is one of the steps the teachers can take to improve their students' self-efficacy and motivation in learning mathematics.

\section{CONCLUSIONS}

The learning activity in each cycle consists of four activities: planning, implementation, observation, and evaluation. The planning activity is conducted through the planning in implementation of the learning process, and in preparing various types of instruments, including the instrument on students' self-efficacy, and motivation in learning mathematics. The second stage is the implementation consisting of two cycles. In the first cycle, the learning implementation did not show results as stated in the predetermined criteria. But in the second cycle, it seems that the students' motivation is higher, and it should always be attempted to improve their learning motivation and their self-efficacy as an effort to increase their learning results. The third activity is observation, namely observing the activities of the learning implementation, and it seems that some students may help one another as an effort to improve their motivation in learning and their self-efficacy.

The last stage is the reflection. From the observation, it can be seen that some students were still not active, and the solution is that some classmates helped one another so that their classroom condition was better. At the end of the session, the materials were concluded, and students were given opportunities to ask questions and made some evaluation through the question-answer session. Viewed from the learning results, it showed that the use of the Cooperative Learning Model with the TGT types showed some improvement in the percentage of the students' self-efficacy, and motivation in learning mathematics occurred in each cycle. The students also gave positive responses to the use of this model, and they also expected that the same model would be adopted for different learning materials.

\section{REFERENCES}

Anandari, S. D. (2013). Hubungan Persepsi Siswa atas Dukungan Sosial Guru dengan Self-Efficacy Pelajaran Matematika pada Siswa SMA Negeri 14 Surabaya. Jurnal Psikologi Pendidikan Dan Perkembangan, 2(3), 8.

Annurwanda, P. (2017). The Effect of Teams Games Tournament on Mathematics SelfEfficacy in Junior High Schools. SHS Web of Conferences, 1-6. https://doi.org/https://doi.org/10.1051/shsconf/20184200079

Asih, J. (2017). Meningkatkan Motivasi Belajar Matematika Melalui Model Pembelajaran Kooperatif Tipe Teams Games Tournament (Tgt) Siswa Kelas Vi Sd Negeri 002 Teluk Nilap Kubu Babussalam. Pendidikan Dan Pengajaran Program Studi Pendidikan Guru Sekolah Dasar FKIP Universitas Riau, 1, 174-180.

Bandura, A. (1994). Self-Efficacy. Encyclopedia of Human Behavior, 4(1994), 71-81. https://doi.org/10.1002/9780470479216.corpsy0836

Bandura, A. (2006). Guide for constructing self-efficacy scales. Self-Efficacy Beliefs of Adolescents, 307-337. https://doi.org/10.1017/CBO9781107415324.004 
Çiftçi, K., \& Yildiz, P. (2019). The effect of self-confidence on mathematics achievement: The meta-analysis of Trends in International Mathematics and Science Study (TIMSS). International Journal of Instruction, 12(2), 683-694. https://doi.org/10.29333/iji.2019.12243a

DeVries, D. L. (1976). Teams-Games-Tournament: A gaming technique that fosters learning. Simulation \& Games, 7(1), 21-33. https://doi.org/10.1177/104687817600700102

Durksen, T. L., Way, J., Bobis, J., Anderson, J., Skilling, K., \& Martin, A. J. (2017). Motivation and engagement in mathematics: a qualitative framework for teacher-student interactions. Mathematics Education Research Journal. https://doi.org/10.1007/s13394017-0199-1

Eshet, Y., Grinautski, K., \& Peled, Y. (2012). Learning motivation and student academic dishonesty: A comparison between face-to-face and online courses. Proceedings of the Chais Conference on Instructional Technologies Research 2012: Learning in the Technological Era, 22-29.

Fitriana, S., Ihsan, H., \& Annas, S. (2015). Pengaruh efikasi diri, aktivitas, kemandirian belajar dan kemampuan berpikir logis terhadap hasil belajar matematika pada siswa kelas viii smp. Journal of EST, 1 No 2(September), 86-101.

Fitriati, T. K. (2017). Meningkatkan Motivasi Belajar Siswa Pada Mata Pelajaran Matematika Melalui Pendekatan Bimbingan Kelompok. Jurnal Bimbingan Konseling, 6, 88-100.

Friedman; Schustack. (2008). Kepribadian Teori Klasik dan Riset Modern (Ketiga). Erlangga.

Herreid, C. F. (1998). Why Isn't Cooperative Learning Used to Teach Science? BioScience, 48(7), 553-559.

Hidayati, S. (2015). Pembelajaran Kooperatif Dengan Tutor Sebaya Pada Materi Ajar Statistika. Dinamika, 05, 1-8.

Huang, C. S. J., Su, A. Y. S., Yang, S. J. H., \& Liou, H. H. (2017). A collaborative digital pen learning approach to improving students' learning achievement and motivation in mathematics courses. Computers and Education. https://doi.org/10.1016/j.compedu.2016.12.014

Ismail, S. N., Muhammad, S., Kanesan, A. G., \& Ali, R. M. (2019). The influence of teachers' perception and readiness towards the implementation of Critical Thinking Skills (CTS) practice in mathematics. International Journal of Instruction, 12(2), 337352. https://doi.org/10.29333/iji.2019.12222a

Johnson, D. W., Johnson, R. T., \& Stanne, M. B. (2000). Cooperative Learning Methods : A Meta-Analysis. Methods, 1(January 2000), 1-33.

Jones, K., \& Jones, J. (2008). Making Cooperative Learning Work in the College Classroom: An Application of the "Five Pillars" of Cooperative Learning to PostSecondary Instruction. The Journal of Effective Teaching, 8(2), 61-76.

Kemmis, S., McTaggart, R., \& Nixon, R. (2014). The Action Research Planner. In The 
Action Research Planner. https://doi.org/10.1007/978-981-4560-67-2

Khan, G. N., \& Inamullah, H. M. (2011). Effect of student's team achievement division (STAD) on academic achievement of students. Asian Social Science, 7(12), 211-215.

Kiemer, K., Gröschner, A., Pehmer, A. K., \& Seidel, T. (2015). Effects of a classroom discourse intervention on teachers' practice and students' motivation to learn mathematics and science. Learning and Instruction. https://doi.org/10.1016/j.learninstruc.2014.10.003

Lilis Maysaroh. (2012). Hubungan Lingkungan Belajar Dengan Prestasi Belajar Geografi Siswa Pemondok dan Siswa Penglaju Madrasah Aliyah Negeri (MAN) Wonokromo.

Major, D. A., Turner, J. E., \& Fletcher, T. D. (2006). Linking proactive personality and the Big Five to motivation to learn and development activity. Journal of Applied Psychology, 91(4), 927-935.

Nurmahmidah. (2017). The Application Of Cooperative Learning Model The type of Teams Games Tournament (TGT) on the subject of Opportunities in an effort to Boost achievement and Motivation learn math Grade X Mia 2 Sma Negeri 1 Sedayu. Jurnal Mercumatika, 1, 139-146.

Nurmayasari, K., \& Murusdi, H. (2015). Hubungan Antara Berpikir Positif Dan Perilaku Menyontek Pada Siswa Kelas X Smk Koperasi Yogyakarta. Jurnal Fakultas Psikologi, 3, 8-15.

Olanrewaju, A. S. (2010). Correlation between Academic Cheating Behavior and Achievement Motivation. Nature and Science, 8, 130-134.

Ormrod, J. E. (2009). Psikologi Pendidikan (Keenam). Erlangga.

Pajares, F. (1996). Self-Efficacy Beliefs in Academic Settings. Review of Educational Research, 66(4), 543-578.

Pratiwi, Alti Sella; Supraptiningsih, E. (2015). Hubungan antara Persepsi Dukungan Wali Kelas dengan Self Efficacy Siswa di SMK TI-Garuda Nusantara. Penelitian Sivitas Akademika Unisba (Sosial Dan Humaniora), 173-179.

Pudjiastuti, E. (2012). Hubungan "Self Efficacy" dengan Perilaku Mencontek Mahasiswa Psikologi. MIMBAR, XXVIII, 103-112. https://doi.org/2303-2499

Ramlan. (2013). Meningkatkan Self-Efficacy Pada Pembelajaran Matematika Melalui Model Kooperatif Tipe Team Assisted Individualitazion (TAI) Pada Siswa Kelas VIIA SMP Negeri 27 Makassar. Jurnal Matematika Dan Pembelajaran (MAPAN), 01, 110.

Salam, A., Hossain, A., \& Rahman, S. (2015). Effects of Using Teams Games Tournaments (TGT) Cooperative Technique for Learning Mathematics in Secondary Schools of Bangladesh. Malaysian Online Journal of Educational Technology, 3(3), 35-45. https://doi.org/10.4471/redimat.2015.1519

Sardiman. (2009). Interaksi dan motivasi belajar mengajar. PT. Raja Grafindo Persada. Shara, S. (2016). Hubungan Self-Efficacy Dan Perilaku Menyontek (Cheating) Pada Mahasiswa Fakultas Psikologi Universitas X. Jurnal Ilmiah Psikologi, 9, 42-49. 
Sharan, S. (1980). Cooperative Learning in Small Groups: Recent Methods and Effects on Achievement, Attitudes, and Ethnic Relations. Review of Educational Research, 50(2), 241-271.

Skaalvik, E. M., \& Skaalvik, S. (2009). Self-concept and self-efficacy in mathematics: Relation with mathematics motivation and achievement. In Motivation in Education.

Slavin, R. E. (1980). Cooperative Learning. Review of Educational Research, 50(2), 315-342. https://doi.org/10.3102/00346543050002315

Soekanto, S. (2000). Sosiologi Suati Pengantar. PT. Raja Grafindo Persada.

Son, A. L., \& Tanines, D. (2016). Meningkatkan Motivasi Dan Prestasi Belajar Matematika Siswa Melalui Model Pembelajaran Kooperatif Tipe Teams Games Tournament. 7, 32-38. https://doi.org/1693-7945

Sunarsih, T. (2009). Hubungan Antara Motivasi Belajar, Kemandirian Belajar Dan Bimbingan Akademik Terhadap Prestasi Belajar Mahasiswa Di STIKES A. Yani Yogyakarta [Universitas Sebelas Maret Surakarta]. In Program Pascasarjana UNS. https://doi.org/10.1017/CBO9781107415324.004

Syamarro, N., Saluky, \& Winarso, W. (2015). Pengaruh Motivasi dan Persepsi Siswa pada Matematika Terhadap Prestasi Belajar Matematika Siswa Kelas VIII di MTs AlHidayah Dukupuntang Kabupaten Cirebon (Pokok Bahasan Kubus dan Balok). Eduma, 4(2), 105-111.

Tarim, K., \& Akdeniz, F. (2008). The effects of cooperative learning on Turkish elementary students' mathematics achievement and attitude towards mathematics using TAI and STAD methods. Educational Studies in Mathematics, 67(1), 77-91.

Tossavainen, T., \& Faarinen, E. C. (2019). Swedish fifth and sixth graders' motivational values and the use of ICT in mathematics education. Eurasia Journal of Mathematics, Science and Technology Education. https://doi.org/10.29333/ejmste/108533

Van Wyk, M. (2011). The Effects of Teams-Games-Tournaments on Achievement, Retention, and Attitudes of Economics Education Students. Journal Social Science, 26(3), 183-193.

Veloo, A., \& Chairhany, S. (2013). Fostering students' attitudes and achievement in probability using teams-games-tournaments. Procedia - Social and Behavioral Sciences, 93, 59-64. https://doi.org/10.1016/j.sbspro.2013.09.152

Wardhani, W. K., Susilo, H., \& Iqbal, M. (2015). Pengaruh Motivasi Kerja Karyawan Terhadap Komitmen Organisasional Dengan Kepuasan Kerja Sebagai Variabel Intervening. Jurnal Administrasi Bisnis, 2, 1-10.

Wizaksana, A. (2012). Teori Motivasi-Hygiene Herzberg Dan Kepuasan Kerja Karyawan Dengan Variabel Mediasi Berupa Pandangan Terhadap Uang (Studi Kasus : PT. X Indonesia Finance).

Zuya, H. E., Kwalat, S. K., \& Attah, B. G. (2016). Pre-Service Teachers' Mathematics Self-Efficacy and Mathematics Teaching Self-Efficacy. Journal of Education and Practice. 